\title{
CONSERVATION OF HERITAGE MASONRY IN CANADA: A CURRENT PERSPECTIVE
}

\section{Nigel SHRIVE ${ }^{i}$ email}

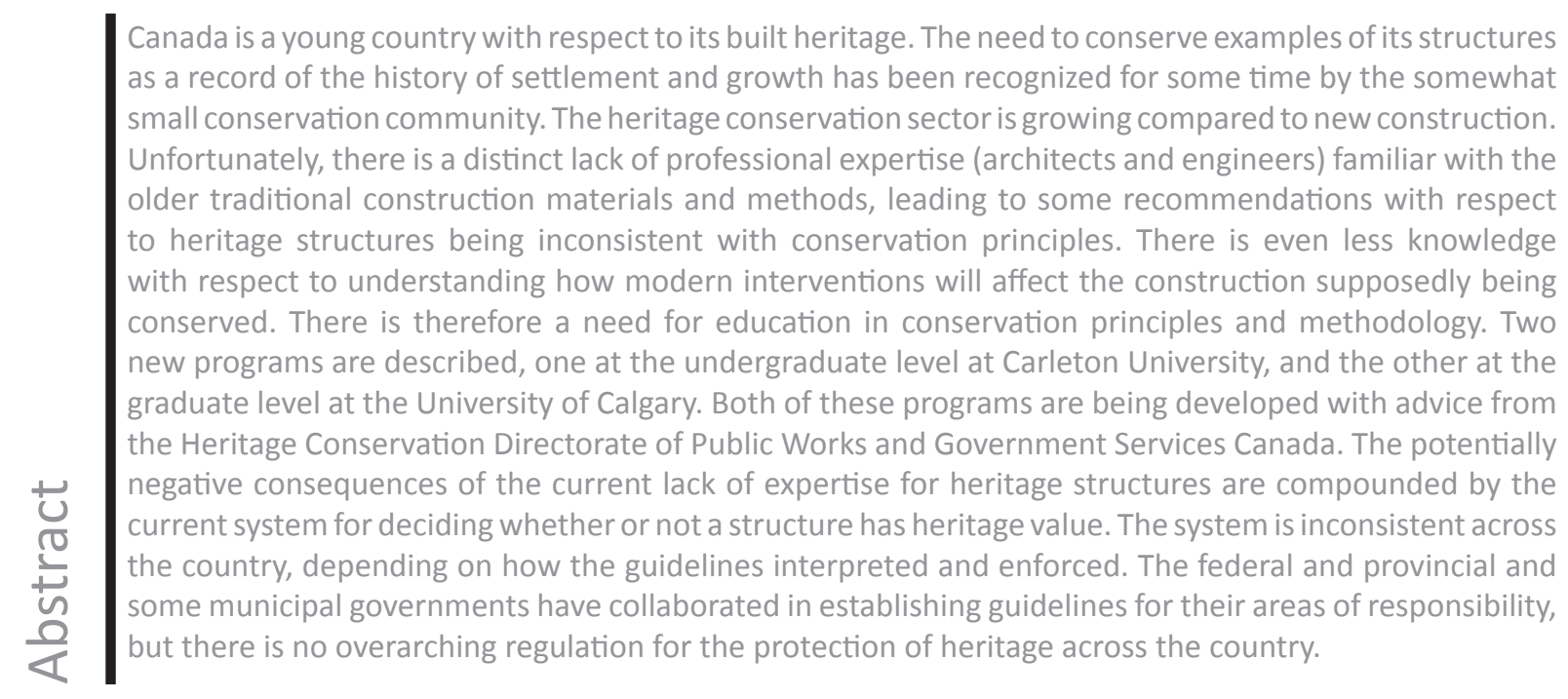

Keywords: heritage, conservation.

This article was originally presented in proceedings of the 15th International Brick and Block Masonry Conference 


\section{INTRODUCTION}

Canada is young in terms of heritage structures compared to most of the rest of the world. Our oldest masonry structures date from the mid $17^{\text {th }}$ century (eg: Figure 1). Many masonry structures were built by immigrants from Europe who used the same techniques they had been taught in their countries of origin, which would typically have been France and Great Britain during initial settlement from that continent. However, the Canadian climate is considerably harsher in terms of freeze-thaw cycles than these masons were accustomed to, consequently the rate of deterioration of these structures was, and can still be, significantly more rapid than one would expect of the same construction in the original homelands of the masons (Figure 2). The need to conserve this relatively young heritage for the benefit of future generations is beginning

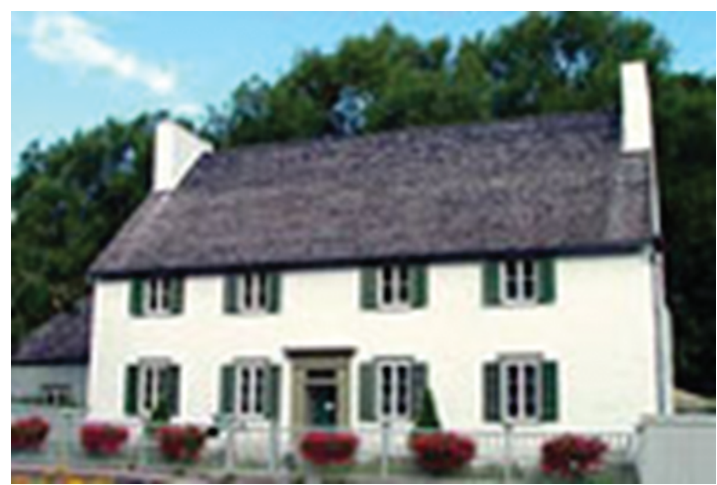

Figure 1. Maison des Jesuites-de-Sillery, 1637, Quebec, from www.ville.quebec.qc.ca. to be recognized nationally. If steps are not taken now in some areas, there may be little to no heritage to conserve - the physical examples of history (including heritage structures) will become history themselves. Here, the current state of practice is assessed, together with education with respect to heritage structures in Canada.

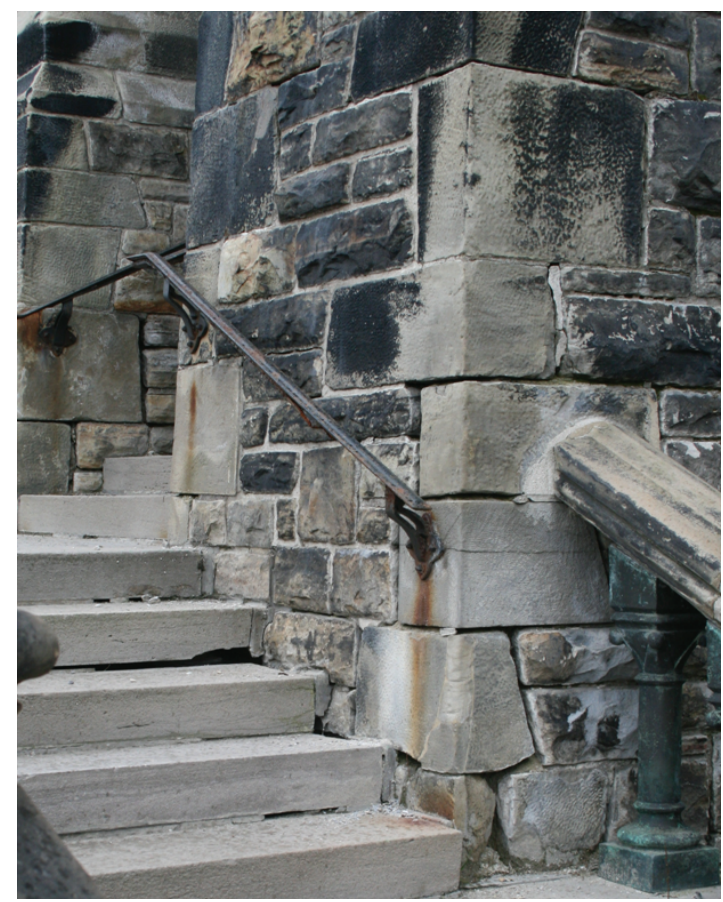

Figure 2. Loss of mortar in stone masonry due to freeze-thaw action.

\section{DURABILITY}

As mentioned, durability is a major issue due to the northern location of Canada and the consequential freeze-thaw cycles through a normal winter. Loss of mortar as shown in Figure 2 is one consequence, the example being from a building on the Parliamentary Precinct in Ottawa, but the units also need to be durable. The piles of deteriorated bricks in Figure 3 are all that remains of a brick plant opened near Calgary on the western edge of the prairies in 1912. The plant produced 100,000 bricks a day with the stiff mud process, but closed in 1914 because the bricks had a reputation for crumbling easily in the climate. Thus conservation has to be in the public eye as more maintenance is required than would be in the country of origin of most immigrants to Canada.

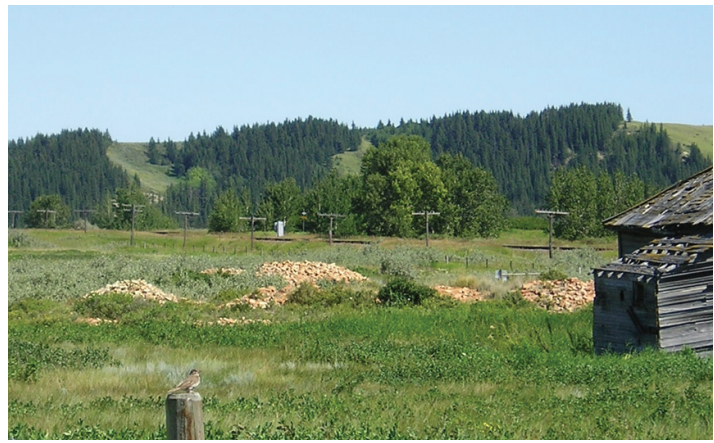

Figure 3. All that remains of a brick plant in Alberta, opened in 1912, closed in 1914. 


\section{GROWING PUBLIC AWARENESS}

Activity with respect to the conservation of heritage structures in Canada is growing as people become aware of the loss of heritage for future generations. In many centres conservation of our past has only recently become a topic of public concern. For example, the Calgary Heritage Initiative Society was formed only in 2005 (www.calgaryheritage. org). The society actively advocates on the value of some of the historic buildings that remain in the city, and the need to conserve them. (Calgary was a sandstone city a hundred years ago, but now very few of those structures remain.) This society works with the Calgary Heritage Authority - a board formed in 1999 through the merger of what was then the Heritage Advisory Board of the city (formed in 1979) with the Calgary Municipal Heritage Properties Authority (established in 1985 by an act of the provincial government). The Calgary
Heritage Authority advises City Council on all matters relating to heritage resources in the city, evaluates potential heritage sites, monitors the effectiveness of legislation which affects heritage conservation objectives and proposes appropriate amendments, and tries to raise awareness of heritage issues in the city. Thus like other communities in Canada, Calgary and its citizens are beginning to recognize the value of heritage conservation and establish the mechanisms for evaluation and implementation. Indeed, the City now offers awards for conservation projects to encourage good practice. In other parts of the country, heritage conservation is more established, with heritage structures being recognized as assets for local communities, nationally or internationally. Conservation of these assets is seen as desirable with assessment and associated action more organized.

\section{CAPACITY FOR THE WORK}

While the monies being spent on conservation are currently much less than on new construction, the conservation sector is growing. One reason for this is the high cost of retrofitting these buildings to increase their seismic resistance, especially stone masonry buildings. The National Building Code of Canada (NBCC) (NATIONAL..., 2010) does not dictate when a structural evaluation of an existing building is required, but these evaluations are typically performed when there is a major change to the use of the building, the building has been damaged or where a major lifecycle retrofit is planned. The work to rehabilitate these structures to modern requirements can take many years. The structural engineering demand to meet these seismic requirements will undoubtedly grow in both design and implementation.

There are several factors which interact to make conservation practice challenging. There are some professionals in the private sector sensitive to conservation issues, but as the volume of work grows, they will be hard-pushed to cope. One of the more obvious factors is the lack of knowledge of the structural systems and materials used in heritage structures for many in the consulting industry. Undergraduate courses in civil engineering concentrate on teaching steel and reinforced concrete design. A study by Shrive and Sturgeon (2001) examined the 26 accredited civil engineering degree programs in Canada and found that masonry received only $1.6 \%$ of the compulsory lecture hours spent on the design of concrete, steel, wood, asphalt and masonry structures and materials, whereas concrete received $47.1 \%$ and steel $41.4 \%$ respectively. When optional hours were added, the time given to masonry rose to $5.3 \%$, but there were fewer students in the optional courses as compared to the compulsory ones. The number of masonry courses was expected to fall as some of the professors offering the courses were due to retire shortly thereafter. Within the course contents, only one university mentioned arches in an optional undergraduate masonry design course. It is clear that graduates of structural engineering programs in Canada are first and foremost taught how to analyse and design concrete and steel structures. They are taught very little about masonry and even less (if anything) about the analysis and design for the rehabilitation of historic structures. The predominance of courses on concrete and steel structures and materials was also repeated in the graduate programs. Hence there is a distinct lack of knowledge in the structural engineering consulting industry on how heritage structures "work". The equivalent numbers in the eleven programs of architecture studied were better although masonry was taught more from a building envelope perspective than as a structural material.

Thus, Canada is beginning to suffer from the concern of Muir Wood (2009) who stated - one presumes with respect to the UK - that "Recent examples of inappropriate analysis of masonry structures, leading to their unnecessary designation as unsafe, 
suggest modern engineers could benefit from a wider appreciation of elementary principles." In concordance with this statement, there have been recommendations recently to demolish stone masonry arch bridges in Ontario, which really only need a bit of restoration work. In the first case, the bridge was about 140 years old with the arch barrel retaining the original shape as seen in early photographs. There was considerable loss of mortar and some stones in the spandrel wall had moved as well as in the wing-walls. There was a compatibility crack at one end of the barrel, between the barrel and the spandrel wall. One consultant recommended that the bridge should be demolished as it was bordering on unsafe, while a second recommended that the fill be removed, a new reinforced concrete arch and spandrel walls be constructed inside the original arch and the fill replaced - the original arch thus becoming a face to the new one. Analysis of the arch showed the line of thrust was easily retained in the kern, and so one wonders why deep repointing of the mortar and realignment of the stones that had moved was not the primary recommendation. In the second case, an old rail bridge, now incorporated in a nature park was being examined. Stone spandrel walls were melded with a double ring brick barrel. Some bricks from the outer ring had fallen and there had been loss of mortar. The first consultant above recommended repointing and replacement of the lost bricks, while the second above recommended the bridge be demolished!

These are examples of how many general practitioners lack the expertise to deal with the increasing volume of work in the heritage conservation area. A natural consequence is that when faced with a conservation project, not only is there little understanding of how a heritage structure functions, there is also little understanding of how a modern intervention will affect the heritage structure. For example, few would know that introducing a stiff steel frame into a wood or masonry structure can be disastrous, as the original structure can no longer deform as it did in the past under varying environmental conditions. Unfortunately most universities lack the educators to teach students about appropriate interventions to historic structures as most in the professoriate have come through a system dominated by concrete and steel, and perpetuate that domination.

\section{CURRENT STATUS OF EDUCATION}

The education of professional architects and engineers as shown above has led to a shortage of professionals who are familiar with the older methods of construction, or have the background to adapt to those methods. As described, there is very little education, and thus experience and knowledge, about how to conserve structures. The emphasis on designing new concrete and steel structures has resulted in there being very few experts, especially engineers, in the private sector who fundamentally understand historic structures. Many others are and will be called upon to investigate and make recommendations concerning old structures. However, some appear not even to be aware of fundamental heritage conservation documents such as the Standards and Guidelines for the Conservation of Historic Places in Canada (Parks Canada, 2010) let alone understand or appreciate conservation theory and philosophy. For example, in assessing a final year project at the University of Calgary, partly involving a designated heritage building in the city, it was evident that the industry advisors were completely unaware that standards and guidelines even existed.

With encouragement from the Heritage Conservation Directorate of PWGSC, there has been some movement to begin education for professionals in this area. Carleton University in Ottawa now offers an undergraduate programs in "Architectural Conservation and Sustainability Engineering" with two sub-streams, one emphasizing environmental aspects and the other structural engineering. In addition to basic mathematics, chemistry, engineering and complementary study courses expected in a normal degree program, the program includes specific courses aimed at conservation and functioning within a conservation team:

$\begin{array}{ll}\text { - } & \text { Introduction to Architecture; } \\ \text { - } & \text { Architecture and the Environment; } \\ \text { - } & \text { History of Structures; } \\ \text { - } & \text { Civil Engineering Materials; } \\ \text { - } & \text { Architectural Technology 3; } \\ \text { Engineering; } \\ \text { - } & \text { Process Analysis for Environmental } \\ \text { - } & \text { Heritage Conservation in Canada; } \\ \text { Systems Modeling; } \\ \text { - } & \text { Introduction to Structural Design; } \\ \text { - } & \text { Architectural Technology 4; } \\ \text { - } & \text { Architectural Conservation, Philosophy } \\ \text { \& } & \text { Ethics; } \\ \text { - } & \text { Historic Site Recording and Assessment; } \\ \text { - } & \text { Introduction to Modern Architecture/ } \\ \text { Microbiology; }\end{array}$


- $\quad$ Recycling Architecture in Canada and Abroad;

- Design Project;

- $\quad$ Green Building Design; and

- Building Pathology and Rehabilitation.

This program has just completed its first year, so it will be some time before the first students graduate. The University of Calgary has offered its first graduate level course "Conservation of Heritage Structures 1" with advice from the Heritage Conservation Directorate. The initial course description was:

"Introduction to heritage conservation. Understanding heritage value. Heritage materials and building systems. Inspection methodology, investigation and monitoring techniques, damage assessment and interpretation. Damage and collapse mechanisms: environmental and time-dependent effects, causes of cracking, durability and protection options. Case studies."

A requirement for registration was a bachelor's degree in civil engineering: students were expected to have a solid knowledge of structures and structural materials. The nine students who took the course received 12 (3 hour) lectures at the University and as part of the first offering of the course, visited Ottawa, where members of HCD and Parks Canada presented lectures on the Federal Government standards, guidelines and processes, giving many examples of their implementation. The students were also taken on-site to Parliament Hill to be shown the theory in practice. A second course "Conservation of Heritage Structures 2" has been proposed with the following content:

"Modeling and analysis: determination of load paths, collapse through stability or strength. Finite element modeling, macro and micro modeling, geometric considerations, material heterogeneity. Risk assessment. Intervention techniques, rehabilitation, strengthening, replacement. Structural and environmental effects of intervention, compatibility of materials. Case studies."

It is hoped that these programs will begin to provide Canada with practicing professionals with appropriate knowledge of conservation principles and practices.

\section{INCONSISTENCY IN DETERMINATION OF HERITAGE STATUS}

The first step in the conservation process in Canada is to determine whether a structure is worth conserving. There is inconsistency across the various jurisdictions as to how and whether heritage status is designated. At the federal level heritage buildings are protected under the Treasury Board Real Property Policy. Parks Canada establishes national goals to protect federal heritage buildings and national historic sites. It also develops policies, standards and guidelines in consultation with other departments. Through the Federal Heritage Buildings Review Office, Parks Canada provides criteria and a process for evaluating and designating heritage character, provides advice and recommendations to other departments, and maintains a register of federal heritage buildings. The minister responsible for the Agency is responsible for approving the heritage designations for federal buildings based on the recommendation of an interdepartmental advisory committee.

Of the roughly 36,000 buildings owned by the federal government, the Federal Heritage Building Review Office has evaluated about 22,000. So far 271 buildings have been classified and 1095 recognized for their heritage value. There are about 200 National Historic Sites, mostly under the care of Parks Canada. The centre of expertise for heritage conservation within the federal government is the
Heritage Conservation Directorate (HCD) of Public Works and Government Services Canada (PWGSC).

The FHBRO Evaluation Criteria are based on international conservation principles. The advisory committee always evaluates federal buildings against the following criteria: Historical Associations, Architecture and Environment. After evaluating an asset, the FHBRO produces a small document about the asset called the "Heritage Character Statement". This statement identifies the character defining elements and thus the key elements that must be protected and conserved so as not to diminish the asset's heritage value.

While the provincial and territorial governments collaborated on the production of the standards and guidelines, they are each responsible for implementing these within their own jurisdictions. There are varying methods of so doing with differing standards across the country for provincial buildings. To add more complexity, the provinces and territories are not responsible for structures owned by municipalities or privately. There is no requirement for these jurisdictions to apply the same guidelines as the higher level governments impose on themselves. Even if the same guidelines are adopted at the different jurisdictional levels, there is no methodology in place to help local 
committees interpret the guidelines in the same way from one locale to the next.

In Quebec, the need for conservation is well recognized, as evidenced in Figure 1, whereas in Calgary, sometimes just a façade is retained. In the early twentieth century, Calgary was known as a "sandstone city", but very few structures from that era now remain, and for those that do, designation as "heritage" can be elusive given the varying ownership. With the current system in Calgary, neither the city nor the province has jurisdiction over privately owned buildings of historic value. A developer may purchase such a heritage building and demolish it without discussion or intervention. It is clear that consistency in designation of heritage status is something that needs to be addressed.

\section{IMPLEMENTATION OF CONSERVATION}

The FHBRO helps the various federal government departments meet their obligations under the policy established by the Treasury Board. This policy applies to all federal structures that are forty or more years old. Parks Canada is the Department responsible for the largest number of heritage structures $-38 \%$ of the federal total, with the Department of National Defence being next in line with $23 \%$. While the FHBRO provides advice, guidance and reviews, it is mainly private sector architects and engineers sometimes in collaboration with the Heritage Conservation Directorate who must devise ways of actually conserving the structures. The decisions of the designers are driven by the "Heritage Character Statement".

At the federal level, interventions proposed for historic places are evaluated against the "Standards and Guidelines for the Conservation of Historic Places in Canada" published by Parks Canada in 2010 (CANADIAN..., 2010 - available at www.historicplaces. ca). This document contains 14 generic standards based on international conventions, of which 9 are general principles related to conservation, 3 are specific to rehabilitation and 2 to restoration, as below:

- $\quad$ Conserve the heritage value of a historic place. Do not remove, replace or substantially alter its intact or repairable character-defining elements. Do not move a part of a historic place if its current location is a character-defining element;

- $\quad$ Conserve changes to a historic place that, over time, have become character-defining elements in their own right;

- $\quad$ Conserve heritage value by adopting an approach calling for minimal intervention;

- $\quad$ Recognize each historic place as a physical record of its time, place and use. Do not create a false sense of historical development by adding elements from other historic places or other properties, or by combining features of the same property that never coexisted;

- $\quad$ Find a use for a historic place that requires minimal or no change to its character-defining elements;

- $\quad$ Protect and, if necessary, stabilize a historic place until any subsequent intervention is undertaken. Protect and preserve archaeological resources in place. Where there is potential for disturbing archaeological resources, take mitigation measures to limit damage and loss of information;

- $\quad$ Evaluate the existing condition of character-defining elements to determine the appropriate intervention needed. Use the gentlest means possible for any intervention. Respect heritage value when undertaking an intervention; - Maintain character-defining elements on an on-going basis. Repair character-defining elements by reinforcing their materials using recognized conservation methods. Replace in kind any extensively deteriorated or missing parts of character-defining elements, where there are surviving prototypes;

- $\quad$ Make any intervention needed to preserve character-defining elements physically and visually compatible with the historic place and identifiable on close inspection. Document any intervention for future reference.

\subsection{Standards relating specifically to Rehabilitation}

- $\quad$ Repair rather than replace characterdefining elements. Where character-defining elements are too severely deteriorated to repair, and where sufficient physical evidence exists, replace them with new elements that match the forms, materials and detailing of sound versions of the same elements. Where there is insufficient physical evidence, make the form, material and detailing of the new elements compatible with the character of the historic place;

- Conserve the heritage value and character-defining elements when creating any new additions to a historic place or any related new construction. Make the new work physically and visually compatible with, subordinate to and indistinguishable from the historic place;

- Create any new additions or related 
new construction so that the essential form and integrity of a historic place will not be impaired if the new work is removed in the future.

\subsection{Standards relating specifically to Restoration}

- $\quad$ Repair rather the replace character-defining elements from the restoration period. Where character-defining elements are too severely deteriorated to repair and where sufficient physical evidence exists, replace them with new elements that match the forms materials and detailing of sound versions of the same elements;

- Replace missing features from the restoration period with new features whose forms, materials and detailing are based on sufficient physical documentary and/or oral evidence.

\section{INTERVENTIONS: ACTUAL AND ESTIMATED CAPACITIES}

When major rehabilitation projects are undertaken on heritage structures, the opportunity is often taken to upgrade the seismic capacity of the building to bring it into line with modern codes and practice. The major difficulties in this process are the determination of the existing seismic resistance and secondly, to establish the level to which the building should be strengthened. These issues pose several problems - for example, what is a satisfactory level? Does one need to be within $10 \%$ of the code seismic requirements value or is $50 \%$ acceptable? But then, how does one know how accurate the estimate is against the still unknown actual resistance? An estimate of the resistance can be made, but will one ever know how good that estimate is? The estimate will be compared to a code value but one does not know how realistic the design shears are because of the uncertainties in the estimation of the building periods, nor how realistic the design accelerations are as they are predicted from a relatively limited set of data. Within Canada, accepted practice is that if the estimated resistance is $60 \%$ or higher of the code "design load", then the building is acceptable. In the case of heritage buildings, especially mass stone masonry buildings; it is often very difficult to meet the $60 \%$ cut off requirement of the code in medium to high seismic risk areas.

The estimated resistance is based on the assumed in situ material properties. The exterior walls of the buildings on Parliament Hill for example, consist of an exterior wythe of sandstone in a sneck pattern - a bonding pattern that results in no continuous horizontal mortar joint across any section of the masonry - wall or pier. The walls have an interior wythe of limestone in running bond with the space between the sandstone and limestone being filled with a rubble core consisting of the shards from dressing the stones for the other wythes and stones of various size and quality, all bonded roughly with mortar. The walls were built by many masons over the various construction campaigns and are therefore of variable quality. In addition, the masonry has suffered from the climate, with extensive degradation to the mortar of the outer sandstone wythe and the bond between this wythe and the rubble core. Thus how does one estimate material properties to be used in a model, when there is such variation, and given there is a current restoration program, what will be the properties and their variability when that program is completed? These properties are extremely important. If the designer chooses material properties that do not take into account the nonlinear behaviour of the materials, the design forces could be unreasonably high. The analysis will thus grossly overestimate the seismic forces in the building resulting in a very heavy handed intervention to "reinforce" (strengthen) the building. This type of intervention could actually stiffen the structure causing it to attract more seismic forces and hence damage the building more in an earthquake. In other words, the intervention could set the stage for the building to fail - precisely the opposite consequence to that intended - the protection of the building.

In addition to assessing and modeling the material properties, we need to understand the capacity of the various elements of the seismic resisting system (the walls with their openings, wall to floor connections, wall to wall connections). Knowledge is needed of the ductility of these elements, their stiffness and the rates of deterioration of that stiffness with increasing damage, their strength and strength degradation with damage, their damping behaviour and how that damping is affected by damage, hysteretic energy dissipation. Also of importance is knowledge of whether a wall that has suffered some damage can still carry the load imposed on that wall by the rest of the building. One way to begin gaining such knowledge is to undertake testing. Testing can provide some of the information needed and can be used to validate the assumptions taken to analyze the building. To help with assessment of the buildings on Parliament Hill, tests were performed on walls representative of those in the buildings. The results from the tests revealed many interesting features, some of 
which have been published (SOROUR et al., 2011; ELMENSHAWI et al., 2010a, b, 2012), and others which are being investigated further. Even though the testing was extensive, the results really only apply to the walls as constructed and under the stresses imposed. How one may adapt the results to walls of similar materials but different widths of the wythes is open to debate. It is a further stretch to apply the results to walls of different proportions and stones. Non-destructive tests could also be performed on the walls in the building in situ such as a load test or mildly destructive tests like a flat-jack test. As there are limitations to the information all tests provide, monitoring can be additionally useful. For example, seismometers could be installed so that the vibration characteristics of the building could be measured in order to calibrate a structural model (e.g. BOSCATO; RUSSO; SCIARRETTA, 2011).

The important issue is that there is a need to take a different approach with these buildings, compared to the design of a new building with current codes of practice. We need to understand how these buildings will respond to a given load. It is inappropriate simply to assume the worst possible condition and overdesign the "strengthening" of the building because that may just make it worse without knowing it and destroy the very asset that we are trying to protect in the first place. The goal is to make it safe for the public and to protect the heritage character of the building for all to enjoy. A restored section of the Westblock on Parliament Hill is shown in Figure 4. With sufficient, relevant knowledge it is possible to achieve good outcomes, but these must be maintained.

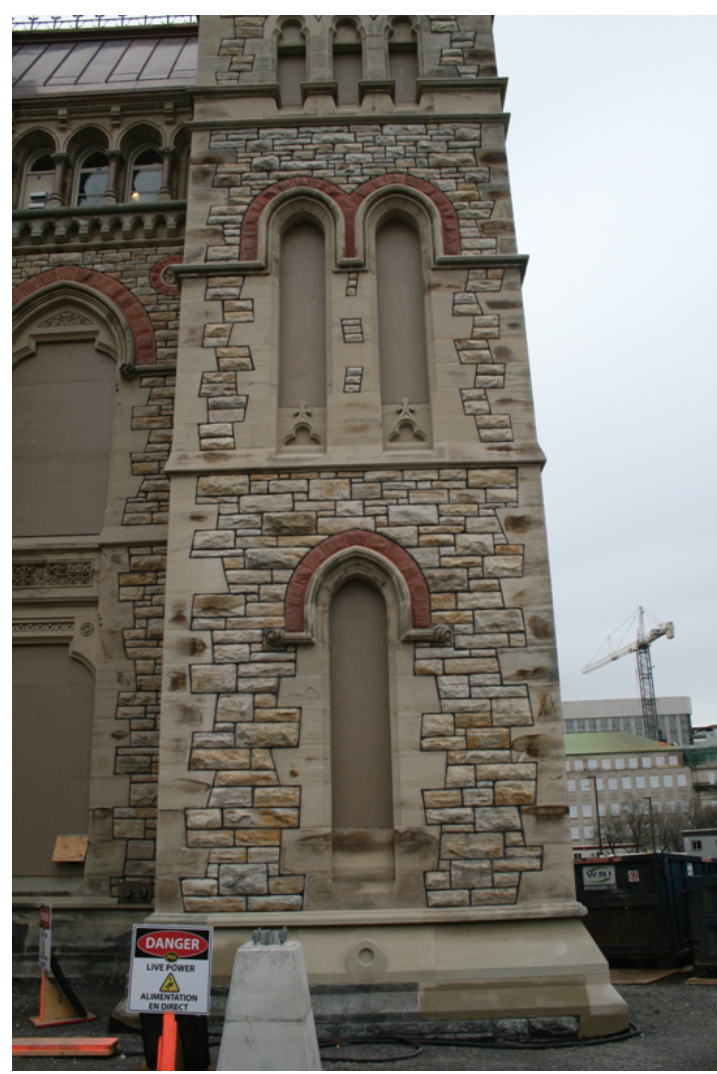

Figure 4. A section of the restored Westblock, on Parliament Hill, Ottawa. Note that the black mortar in the Nepean sandstone and the red mortar to match the red Potsdam sandstone above the windows follows photographic and written evidence that this was the form of the original construction.

\section{CONCLUSION}

Canada is learning from the rest of the world, and it is hoped that as knowledge spreads, more of the Canadian built heritage can be conserved for future generations. Other countries that have been built on the back of European emigration in the last few centuries will have similar problems to those discussed for Canada, except possibly the durability issue. Pooling of knowledge and resources might help conserve more structures as examples of the development of these countries. Older, more established cultures have been looking after their heritage and have much to offer countries developing their heritage conservation strategies. 


\section{REFERENCES}

BOSCATO, G.; RUSSO, S.; SCIARRETTA, F. Structural Monitoring of the Slender Double-layered Façade of Palazzo Ducale in Venice - Preliminary Analysis of Measurements. Masonry International, Edinburgh, v. 24, n. 3, p. 57-72, 2011.

ELMENSHAWI, A. et al. Damping Mechanisms and Damping Ratios in Vibrating Unreinforced Stone Masonry. Engineering Structures, Guildford, v. 32, p. 3269-3278, 2010a. http://dx.doi.org/10.1016/j. engstruct.2010.06.016

ELMENSHAWI, A. et al. In-plane Seismic Behaviour of Historic Stone Masonry. Canadian Journal of Civil Engineering, Ottawa, v. 37, n. 3, p. 465-476, 2010b. http://dx.doi.org/10.1139/L09-166

ELMENSHAWI, A.; SHRIVE, N. G. Assessment of multi-wythe stone masonry subjected to seismic hazards. Earthquake Engineering and Structural Dynamics, Sussex, 2012. Accepted subject to revision.

NATIONAL RESEARCH COUNCIL OF CANADA. National Building Code of Canada. Ottawa: National Research Council, 2010.

MUIR WOOD, A. Thomas Young and the Brunels: masters of masonry analysis. Proceedings of the Institution of Civil Engineers, Civil Engineering, London, v. 162, p. 42-48, 2009. http://dx.doi.org/10.1680/ cien.2008.162.1.42

CANADIAN REGISTER. Standards and Guidelines for the Conservation of Historic Places in Canada, A Federal, Provincial and Territorial Collaboration. Parks Canada. 2nd ed. Canadian Register, 2010. Disponível em: $<$ www.historicplaces.ca $>$.

SOROUR, M. M. et al. An Experimental Program for Determining the Characteristics of Stone Masonry Walls. Canadian Journal of Civil Engineering, Ottawa, v. 38, n. 11, p. 1204-1215, 2011. http://dx.doi.org/10.1139/ $\underline{\mathbf{1 1 1 - 0 8 3}}$

SHRIVE, N. G.; STURGEON, G. Masonry Education in Canadian Post-Secondary Institutions. In: CANADIAN MASONRY SYMPOSIUM, 9., 2001, Fredericton. Proceedings... Fredericton, 2001. 12 p. CD-ROM.

\section{ACKNOWLEDGEMENTS}

The support of the Heritage Conservation Directorate of Public Works and Government Services Canada, the ISIS (Intelligent Sensing of Innovative Structures) Network of Centres of Excellence, The Natural Sciences and Engineering Research Council of Canada and The University of Calgary in supporting the work described, is gratefully acknowledged. In particular I would like to thank Don Duchesne of the HCD for his encouragement and thoughtful comments.

DADOS DOS AUTORES

(i) D.Phil, Professor, University of Calgary, Civil Engineering Department, ngshrive@ucalgary.ca 